\title{
A COLORFUL NEW SPECIES OF NEOOREOPHILUS (ORCHIDACEAE: PLEUROTHALLIDINAE) FROM THE EASTERN ANDES OF COLOMBIA AND ECUADOR
}

\author{
Sebastián VieIra-Uribe ${ }^{1,2,4} \&$ LOU Jost ${ }^{3}$ \\ ${ }^{1}$ Sociedad Colombiana de Orquideología, Medellín, Colombia \\ ${ }^{2}$ Grupo de Investigación en Orquídeas, Ecología y Sistemática Vegetal, Universidad Nacional, \\ sede Palmira, Colombia \\ ${ }^{3}$ Fundación EcoMinga, Baños, Tungurahua, Ecuador \\ ${ }^{4}$ Corresponding author: utricseb@gmail.com
}

\begin{abstract}
A new species of Neooreophilus from the eastern Andes of Colombia and Ecuador is described and illustrated. Neooreophilus chaoae is related to a group of species that includes $N$. cordilabius, $N$. chelosepalus and $N$. werneri characterized by having an obovate, pubescent dorsal sepal and spread or reflexed, non-pubescent lateral sepals ending with an apiculum. The new species can be distinguished by its narrowly triangular lateral sepals and its lip with lateral lobes not extending beyond the column. Notes about its natural habitat and conservation status are also given.
\end{abstract}

Keywords: Neooreophilus, Pleurothallidinae, new species, eastern Andes

Neooreophilus Archila, formerly known as Oreophilus W.E. Higgins \& Archila, Brachycladium Luer, or Lepanthes subg. Brachycladium Luer, is one of the most cryptic and poorly known genera of subtribe Pleurothallidinae (Orchidaceae). The genus is more closely related to Andinia Luer (Wilson \& Jost, 2011) than to Lepanthes Sw., where most of the species had originally been placed. Plants of this genus are epiphytes and form long pendent chains (sometimes exceeding one meter in length) of tiny alternating ovate leaves (5-12 mm long), each on a very short (less than $2 \mathrm{~mm}$ ) ramicaul. The chains hang from tree branches or trunks in very wet mossy cloud forests with good air movement, and closely resemble some pendent fern fronds found in the same habitat. Older leaves are often covered with bryophytes and algae. Inconspicuous tiny but complex flowers are born on racemes from a joint in the ramicaul. The plants are often restricted to narrow elevation bands and are usually rare even in suitable habitat, though when one species is present on a tree, individuals of other species of the same genus often accompany it. Non-specialist botanists rarely notice the flowers, or even the plants, so members of this genus are poorly represented in the world's herbaria.
The new species described below was discovered independently about 10 years apart in two widely separated locations: the Cordillera Abitagua in the east-central Andes of Ecuador, and the Sibundoy Valley in the southeastern Andes of Colombia, ca. 300 $\mathrm{km}$ away. On morphological grounds it appears to be most closely related to Neooreophilus werneri (Luer) Archila and $N$. cordilabius (Luer) Archila from the Andes of southeastern Ecuador, and $N$. chelosepalus (Luer \& Hirtz) Archila, which is thought to have been collected in the Andes of western Ecuador.

Neooreophilus chaoae S. Vieira-Uribe \& L. Jost, $s p$. nov.

TYPE: COLOMBIA. Putumayo: municipio de San Francisco, Vereda Porotal, Reserva Yumartán, 2200 m. Jun. 26 2015. Collected by Miguel M. Bonilla. $S$. Vieira 0020 (holotype: JAUM!). (Fig. 1-2).

Diagnosis.- This species is most similar to Neooreophilus chelosepalus; however, it can be recognized by its narrowly triangular lateral sepals more than twice as long as wide, sub-orbicular lip with lateral lobes not extending beyond the column, and its involute, pubescent petals. 

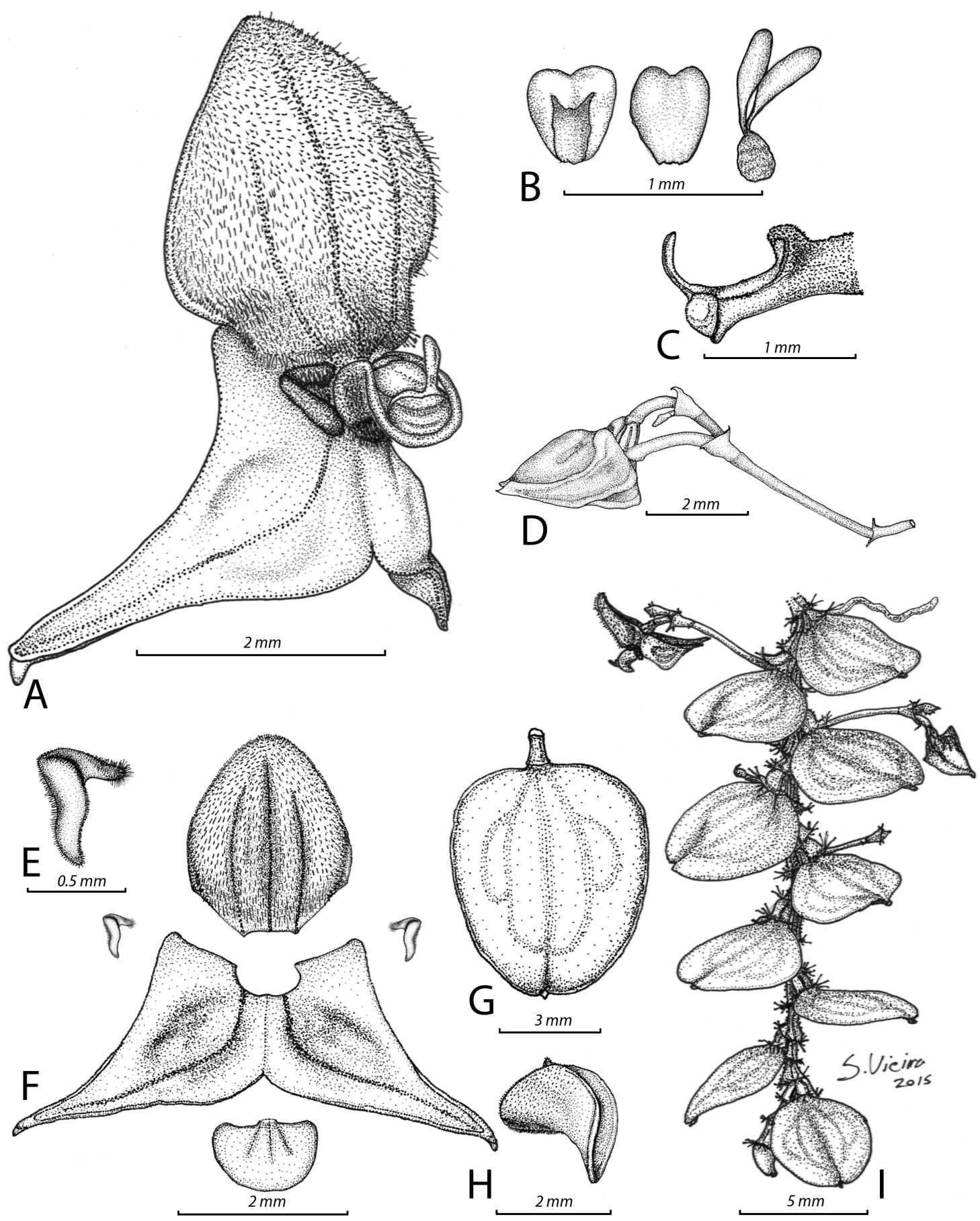

Figure 1. Drawing of Neooreophilus chaoae S. Vieira-Uribe \& L. Jost. A. Flower. B. Pollinia and anther cap. C. Column, profile view (pollinia and anther cap absent). D. Inflorescence. E. Petal. F. Dissected perianth. G. Leaf. H. Lip, profile view. I. Habit. Drawn by S. Vieira-Uribe from S. Vieira 0020 (holotype: JAUM). 
Plant epiphytic, repent and pendent, up to $50 \mathrm{~cm}$ long. Stem 2.5-3.0 $\mathrm{mm}$ long between ramicauls, each segment enclosed by two imbricating, membranaceous, infundibular sheaths, ciliate along the ribs, with dilated, ciliated ostia. Roots slender, flexuous, ca. $0.4 \mathrm{~mm}$ in diameter. Ramicauls $1 \mathrm{~mm}$ long, enclosed by a single membranaceous, infundibular sheath ciliate along the ribs, with dilated, ciliate ostia. Leaves $5.5 \times 4.5$ $5.0 \mathrm{~mm}$, green, suffused with purple along the veins, thickly coriaceous, ovate, obtuse, glabrous, retuse with a short abaxial apiculum at the sinus, the rounded base narrowing into a short petiole less than $0.2 \mathrm{~mm}$ long. Inflorescence a congested, successively flowered raceme placed well above the leaf surface, producing several flowers, often with a last non-developing flower that remains as a vestigial bud; borne by a slender, ascending peduncle $5 \mathrm{~mm}$ long, with a glabrous, tubular sheath, ciliate along the margins, $1 \mathrm{~mm}$ long; up to five inflorescences are borne successively from near the base of each ramicaul; rachis segments ca. $1.5 \mathrm{~mm}$ long; floral bracts infundibular, oblique, acuminate, membranaceous, sparsely ciliate along its margins, ca. $0.8 \mathrm{~mm}$ long; pedicels slender, persistent, $1 \mathrm{~mm}$ long; ovary glabrous, ca. $0.6 \mathrm{~mm}$ long. Flowers facing down. Dorsal sepal $2.3 \times 2.0 \mathrm{~mm}$, orange-red, suffused with burgundy basally, ovate, obtuse, revolute, entire, pubescent, 3-veined, abaxially carinate along the main vein, connate to the lateral sepals for about 1.0 $\mathrm{mm}$. Lateral sepals $3.2 \times 1.5 \mathrm{~mm}$, yellow, suffused with burgundy in the middle, narrowly triangular, acute, reflexed, entire, glabrous, 2-veined, abaxially carinate along the main vein, the carinae ending at the apex with an apiculum, connate for about $0.8 \mathrm{~mm}$. Petals $0.3 \times 0.5$ $\mathrm{mm}$, orange-red, transversally bilobed; the upper lobe triangular, pubescent, $0.4 \mathrm{~mm}$ long; the lower lobe oblong to triangular, slightly sigmoid, involute, puberulous, 0.5 $\mathrm{mm}$ long. Lip $0.8 \times 1.1 \mathrm{~mm}$ when expanded, fulvous, suffused with burgundy in the center, sub-orbicular, entire, glabrous, abaxially puberulous along the veins, 3-veined, embracing the column, cuneate at the base, adnate to the base of the column. Column $1.6 \mathrm{~mm}$ long including the rostellum, white, suffused with lilac, terete, papillulose, the anther and stigma apical; the rostellum apically yellow, oblanceolate, antrorse, conspicuous. Pollinia two, yellow, ovoid, basally filiform, with a transparent drop-like viscidium. Anther cap cream, triangular, cucullate.
Eponymy: We name this species after Dr. Anne Chao of the Institute of Statistics, National Tsing Hua University, Taiwan, in honor of her support for conservation of Fundacion EcoMinga, whose Rio Zuñac Reserve in Ecuador now protects the site where this species was originally discovered. It is also appropriate to name this species in honor of Dr. Chao for her groundbreaking work on the estimation of the number of undetected species in an ecosystem, and for her other important work on the mathematics of biodiversity.

Additional material examined: ECUADOR. Tungurahua: Baños township, Cordillera Abitagua, Rio Zuñac watershed, ca. 2300 m. Nov. 2001. Lou Jost 3408 (QCA!) (Fig. 3B).

Neooreophilus chaoae is vegetatively similar to many of its congeners, with glabrous ovate leaves whose main veins are usually purple (most obvious on young leaves). It belongs to a group of similarly flowered species, with ovate, pubescent dorsal sepal, and reflexed non-pubescent lateral sepals with an apiculum. Its inflorescence is longer than the leaf and the flowers are unusual for the genus in facing downwards. Its glabrous, triangular lateral sepals longer than the dorsal sepal easily distinguish it from all congeners except $N$. cordilabius, $N$. chelosepalus and $N$. werneri. It can be distinguished from $N$. chelosepalus (Fig. 3A) and N. werneri (Fig. 3C) by the narrowly triangular lateral sepals more than twice as long as wide (rather than less than twice as long as wide), its sub-orbicular lip with lateral lobes not extending beyond the column (rather than extending vertically beyond the column [Luer 2002, 2009]) and its pubescent petals (rather than glabrous or cellular glandular). From N. cordilabius, it can be distinguished by its narrowly triangular, glabrous lateral sepals (rather than elliptical-oblong and microscopically pubescent [Luer 2002]), its glabrous ovary (rather than long ciliate-spiculate) and its involute, oblong petals with the upper lobe smaller than the lower lobe (rather than lunate, with lobes equal).

Habitat and conservation status: Neooreophilus chaoae is rare and local at both its known localities. At each site it is restricted to elevations between 2100 and $2500 \mathrm{~m}$ in very wet, airy cloud forest, where it grows 


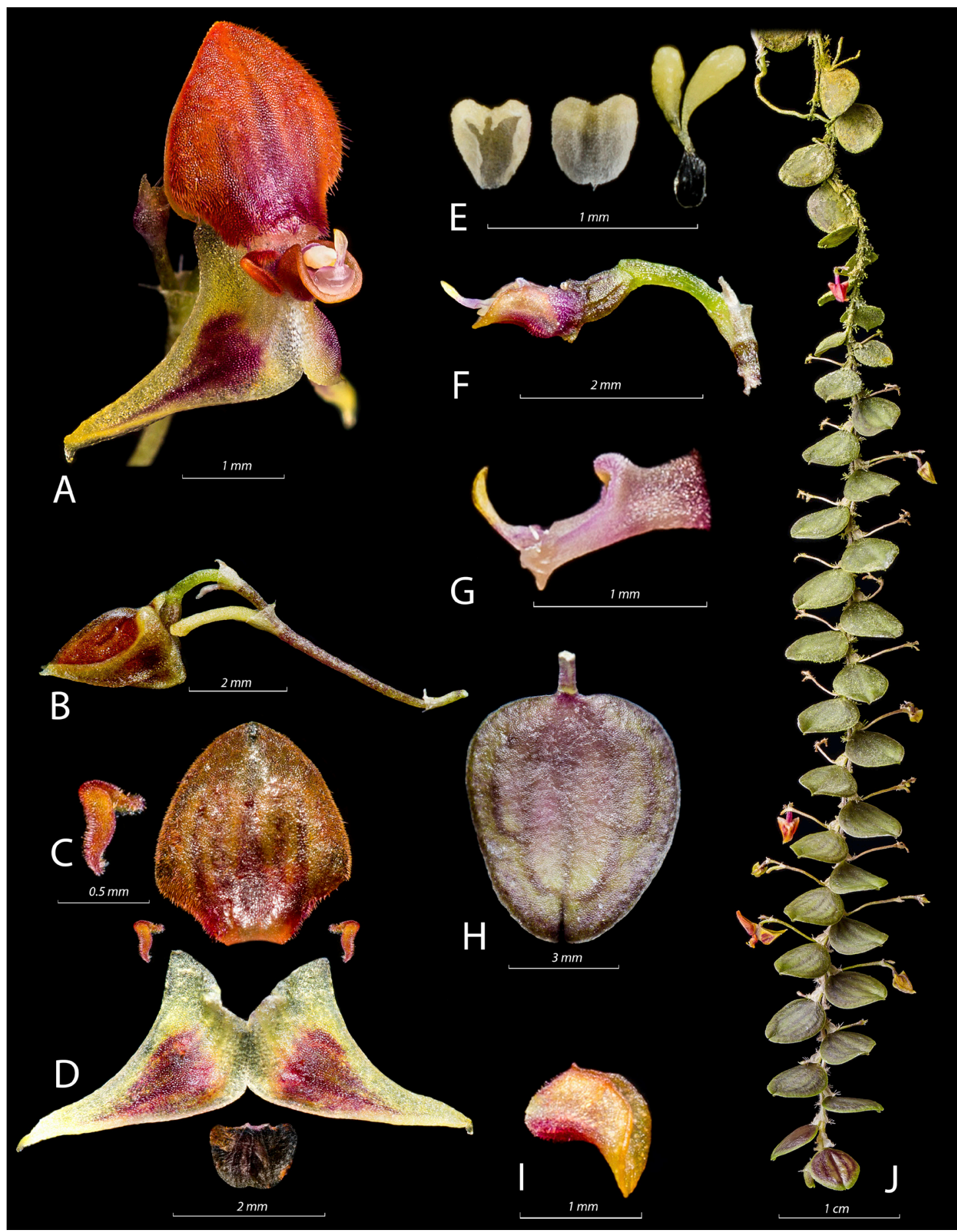

Figure 2. Lankester Composite Digital Plate (LCDP) of Neooreophilus chaoae S. Vieira-Uribe \& L. Jost. A. Flower. B. Inflorescence. C. Petal. D. Dissected perianth. E. Anther cap and pollinia with drop-like viscidium. F. Ovary with column and lip, profile view (pollinia and anther cap absent). G. Column, profile view (pollinia and anther cap absent). H. Leaf. I. Lip, profile view. J. Habit. Photographed by S. Vieira-Uribe from S. Vieira 0020 (holotype: JAUM). 


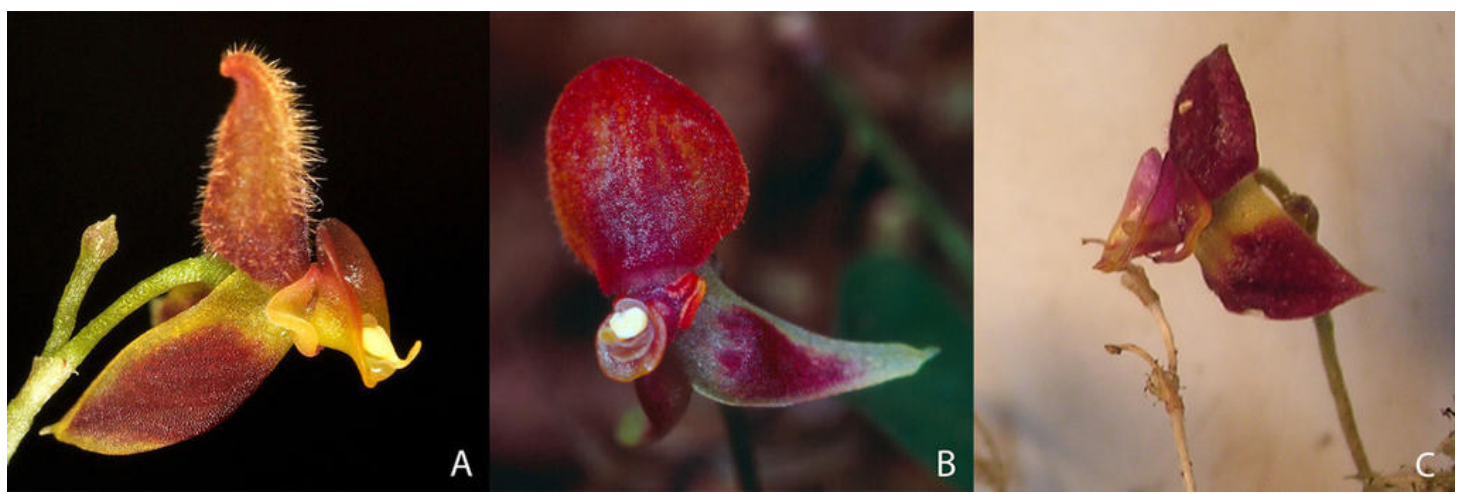

Figure 3. A. Photograph of the flower of Neooreophilus chelosepalus. Photographed by Ron Parsons from a plant grown by Marni Turkel. B. Photograph of the flower of Neooreophilus chaoae from Ecuador. Photographed by L. Jost from Lou Jost 3408 (QCA). C. Photograph of the flower of Neooreophilus werneri. Photographed by Florian Werner from F. Werner 333 (holotype: MO).

together with several other species of the same genus. However, the lack of morphological variation among the specimens from the two distant sites suggests that the known populations are linked by undiscovered populations at similar elevations in the poorly explored northeast Andes of Ecuador. The eastern Andes of southeast Colombia are also quite unexplored, so the distribution of the species may also extend well north of the single known site (Sibundoy valley) in that country. In light of the lack of exploration of suitable nearby habitat, and the cryptic nature of the plants, we suggest classifying this species under the IUCN category "Data Deficient". Both known sites are privately protected; the Ecuadorian site is inside the Fundación EcoMinga's Rio Zuñac Reserve and the Colombian site is inside the Yumartán reserve near Sibundoy valley.

Acknowledgements. The authors want to thank: the Ministerio del Ambiente del Ecuador and the Autoridad Nacional de Licencias Ambientales of Colombia for granting the permits under which specimens were collected; Ramiro Medina from Sibundoy, for providing the first photographs and information about this species in Colombia; Mario Camilo Barrera, from San Francisco, Putumayo, for guiding us to Neooreophilus heaven in Sibundoy Valley, Yumartán Reserve; Steve Beckendorf and Peter Tobias of the Orchid Conservation Alliance for inviting me to join them on a conservation trip to Sibundoy Valley, Miguel M. Bonilla for kindly providing the Colombian material, Alex Hirtz and Ron Parsons, for providing photos of $N$. chelosepalus, and Florian Werner for providing photos of $N$. werneri. Lou Jost gratefully acknowledges support from a grant by John V. Moore to the Population Biology Foundation.

\section{LiTERATURE CITED}

Luer, C. A. (2002). Icones Pleurothallidinarum XXIV: A first century of new species of Stelis of Ecuador Part 1, Addenda to Lepanthes of Ecuador. Monographs in Systematic Botany from the Missouri Botanical Garden, 88, 87-96.

Luer, C. A. (2009). Miscellaneous new species in the Pleurothallidinae (Orchidaceae). Selbyana, 30(1), 1617.

Wilson, M. \& Jost, L. (2011). Phylogenetic analysis of the Andean genus Brachycladium Luer (syn. Oreophilus Higgins \& Archila) and closely related genera based on nuclear ITS sequencing. Lankesteriana, 11(3), 370. 
